Article

\title{
Co-Digestion of Kitchen Waste with Grass and Leaves after Hyperthermophilic Pretreatment for Methane and Hydrogen Production
}

\author{
Przemysław Liczbiński and Sebastian Borowski *D
}

check for updates

Citation: Liczbiński, P.; Borowski, S. Co-Digestion of Kitchen Waste with Grass and Leaves after Hyperthermophilic Pretreatment for Methane and Hydrogen Production. Energies 2021, 14, 5880. https:// doi.org/10.3390/en14185880

Academic Editor: Dino Musmarra

Received: 10 August 2021

Accepted: 14 September 2021

Published: 17 September 2021

Publisher's Note: MDPI stays neutral with regard to jurisdictional claims in published maps and institutional affiliations.

Copyright: (c) 2021 by the authors. Licensee MDPI, Basel, Switzerland. This article is an open access article distributed under the terms and conditions of the Creative Commons Attribution (CC BY) license (https:// creativecommons.org/licenses/by/ $4.0 /)$.
Department of Environmental Biotechnology, Faculty of Biotechnology and Food Sciences, Lodz University of Technology, 90-924 Lodz, Poland; przemyslaw.liczbinski@dokt.p.lodz.pl

* Correspondence: sebastian.borowski@p.lodz.p1

Abstract: The study investigated co-digestion batch experiments using kitchen waste (KW) and garden waste $(\mathrm{GW})$ collected from individual households. Grass and leaves were first subjected to a 3-day hyperthermophilic pretreatment at $70{ }^{\circ} \mathrm{C}$ and $80^{\circ} \mathrm{C}$ and then co-digested with kitchen waste at $35^{\circ} \mathrm{C}$ and $55^{\circ} \mathrm{C}$. The hyperthermophilic pretreatment resulted in the solubilization of organic material with the release of fatty acids, whereas the biogas yield was negligible. In the second stage, the greatest methane yield of $387 \mathrm{NmL} / \mathrm{gVS}$ was achieved for the mono-digestion of leaves, whereas the co-digestion of grass with $50 \% \mathrm{KW}$ gave the highest hydrogen production of $88 \mathrm{NmL} / \mathrm{gVS}$. Considering the overall process performance, the best operating conditions were established using a 3-day hyperthermophilic pretreatment at $70{ }^{\circ} \mathrm{C}$, followed by co-digestion at $55^{\circ} \mathrm{C}$ in the second stage for the mixture of $25 \%$ garden waste with $75 \% \mathrm{KW}$.

Keywords: hydrogen; methane; hyperthermophilic treatment; grass; leaves; kitchen waste

\section{Introduction}

With the depletion of fossil fuels and their impact on the environment, the share of energy produced from renewable sources, including biomass, increases every year. On 2 December 2015, the European Commission implemented the concept of Circular Economy (CE) [1], which assumes the longest possible use of products and resources in order to reduce waste generation at all stages of the production process. Moreover, byproducts that have not been reused should be utilized, to generate energy for instance [2-4]. According to the Central Statistical Office, in 2018, more than 12 thousand tons of municipal waste were generated in Poland, and this amount was $4.3 \%$ greater than in the previous year. This corresponds to $325 \mathrm{~kg}$ of municipal waste produced per person in 2018 [5]. Considering individual households, two main groups of this waste are generated, namely kitchen waste and garden waste. The first group accounts for $15-63 \%$ of all municipal solid waste and is characterized by significant water and nitrogen content showing a carbonto-nitrogen $(\mathrm{C} / \mathrm{N})$ value of 9-21 [6,7]. Garden waste, mainly grass and leaves, consists of lignocellulosic materials that are cheap and widely available; therefore, they are potentially attractive for methane and hydrogen production [8-10]. This waste is traditionally treated by composting, in which actinomycetes and fungi provide enzymes that degrade the lignocellulosic structures. In contrast, the degradation rate of lignocellulosic materials by anaerobic bacteria is limited; hence, garden waste needs preliminary treatment before being subjected to biogas production. Previous studies have shown that thermal pretreatment at $70{ }^{\circ} \mathrm{C}$ considerably increases the biogas yield from both grass and leaves [11]. On the other hand, a generally large concentration of carbohydrates and the low $\mathrm{pH}$ of food and kitchen waste make these materials difficult to treat alone due to the rapid acidification and inhibition of methanogenesis in the digesters [12]. Considering the above, the codigestion of kitchen waste with hyperthermophilically pretreated grass and leaves seems to 
be an attractive approach to utilizing both waste types produced in individual households. Moreover, the treatment of nitrogen-rich kitchen waste with grass and leaves, which are more abundant in phosphorus and sulfur, provides a more balanced mixture and may increase biogas production.

A two-step anaerobic treatment with a hyperthermophilic pretreatment first stage has already been investigated using various substrates, including kitchen garbage and excess sludge [13]; kitchen waste and polylactide [14]; and the mixture of grass with sewage sludge [15]. According to these studies, the highest biogas production could be achieved when the hyperthermophilic pretreatment was combined with thermophilic digestion in a subsequent stage. In contrast, Abbreu et al. [16] successfully applied a two-step hyperthermophilic-mesophilic digestion process for the treatment of garden and food waste. The authors reported that hydrogen was produced in the hyperthermophilic stage, whereas methane was generated in the mesophilic step. Furthermore, hydrolysis was improved by Caldicellulosiruptor saccharolyticus, which was used to inoculate the hyperthermophilic reactor.

Due to a generally high biodegradability, kitchen waste does not need to be preliminarily treated before being subjected to biogas production. Hence, in this work a new concept of co-digestion was proposed and evaluated, according to which garden waste (grass and leaves) was thermally pretreated at $70^{\circ} \mathrm{C}$, then mixed in different proportions with kitchen waste and anaerobically digested at mesophilic and thermophilic temperatures with the aim of maximizing methane and hydrogen production.

\section{Results and Discussion}

\subsection{Characteristics of Substrates and Inoculum}

The characteristics of the substrates and inoculum used in this study are shown in Table 1. All the materials were abundant in volatile solids, the concentrations of which exceeded $90 \%$ TS. The grass and the leaves had similar contents of carbon $(59.9 \%$ TS and $58.8 \%$ TS, respectively) and nitrogen (2.68\% TS and $2.89 \%$ TS, respectively), giving a C/N ratio slightly above 20, which is regarded as optimal for stable anaerobic digestion [17]. On the other hand, the concentrations of phosphorus and sulfur in the grass were much greater than the corresponding values for the leaves, making the former substrate more suitable for biological treatment. In contrast, the kitchen waste showed a higher nitrogen content of $4.16 \%$ TS with low amounts of phosphorus and sulfur $(0.25 \%$ TS and $0.31 \%$ $\mathrm{TS}$, respectively). These results clearly indicate the complementary characteristics of both substrate types when considering their application for co-digestion.

Table 1. Characteristics of materials used in the study.

\begin{tabular}{|c|c|c|c|c|c|c|c|c|}
\hline \multirow[b]{2}{*}{ Material } & \multicolumn{8}{|c|}{ Indicator } \\
\hline & $\begin{array}{l}\text { Total Solids } \\
\text { (g/kg) }\end{array}$ & $\begin{array}{c}\text { Volatile Solids } \\
\text { (g/kg) }\end{array}$ & $\begin{array}{l}\text { Carbon } \\
\text { (\% TS) }\end{array}$ & $\begin{array}{l}\text { Nitrogen } \\
\text { (\% TS) }\end{array}$ & $\begin{array}{l}\text { Phosphorus } \\
\text { (\% TS) }\end{array}$ & $\begin{array}{l}\text { Hydrogen } \\
\text { (\% TS) }\end{array}$ & Sulfur (\% TS) & $\mathrm{C} / \mathrm{N}$ \\
\hline Grass & $\begin{array}{c}133.75 \pm \\
11.20\end{array}$ & $109.57 \pm 9.88$ & $59.92 \pm 3.36$ & $2.68 \pm 0.09$ & $0.96 \pm 0.07$ & $5.42 \pm 0.36$ & $0.88 \pm 0.02$ & 22.36 \\
\hline Leaves & $936.20 \pm 5.40$ & $821.21 \pm 6.25$ & $58.80 \pm 2.06$ & $2.89 \pm 0.15$ & $0.27 \pm 0.02$ & $5.41 \pm 0.28$ & $0.34 \pm 0.02$ & 20.35 \\
\hline $\begin{array}{l}\text { Kitchen } \\
\text { waste }\end{array}$ & $256.34 \pm 6.21$ & $245.39 \pm 5.42$ & $54.40 \pm 2.18$ & $4.16 \pm 0.48$ & $0.25 \pm 0.03$ & $5.94 \pm 0.28$ & $0.31 \pm 0.03$ & 15.23 \\
\hline Inoculum & $28.25 \pm 0.72$ & $22.46 \pm 0.34$ & $62.80 \pm 2.80$ & $6.49 \pm 0.16$ & $1.25 \pm 0.05$ & $5.88 \pm 0.26$ & $0.60 \pm 0.03$ & 9.68 \\
\hline
\end{tabular}

\subsection{Hyperthermophilic Treatment of Grass and Leaves}

In previous studies, the hyperthermophilic preliminary treatment was found to considerably increase the methane and hydrogen yield from grass and leaves in the subsequent mesophilic and thermophilic step and overall process performance. On the other hand, the single-stage anaerobic mesophilic or thermophilic treatment of these materials is characterized by low efficiency due to the specific structure of grass and leaves, which are 
mainly composed of recalcitrant lignocellulosic compounds [18]. As mentioned above, the hyperthermophilic pretreatment was only applied to grass and leaves as they were much more resistant to biological treatment than kitchen waste. The efficiency of pretreatment was evaluated based on biogas production in the subsequent co-digestion; however, the digestates from this step were also analyzed for $\mathrm{pH}$ and SCOD, as well as for concentrations of fatty acids and ammonium nitrogen (Table 2).

Table 2. Operating parameters, methane and hydrogen yields, and characteristics of digestates of the hyperthermophilic pretreatment step.

\begin{tabular}{|c|c|c|c|c|c|}
\hline & & Grass $70^{\circ} \mathrm{C}$ & Grass $80^{\circ} \mathrm{C}$ & Leaves $70^{\circ} \mathrm{C}$ & Leaves $80^{\circ} \mathrm{C}$ \\
\hline \multicolumn{2}{|c|}{ Duration time $(\mathrm{d})$} & 3 & 3 & 3 & 3 \\
\hline \multicolumn{2}{|c|}{ Mass of water $(\mathrm{g})$} & 250 & 250 & 350 & 350 \\
\hline \multicolumn{2}{|c|}{ Mass of grass (g) } & 250 & 250 & 0 & 0 \\
\hline \multicolumn{2}{|c|}{ Mass of leaves $(\mathrm{g})$} & 0 & 0 & 150 & 150 \\
\hline \multicolumn{2}{|c|}{ Initial $\mathrm{pH}$ of the mixtures } & $7.22 \pm 0.05$ & $7.17 \pm 0.09$ & $6.95 \pm 0.07$ & $6.98 \pm 0.03$ \\
\hline \multicolumn{2}{|c|}{ Hydrogen yield (NmL/gVS) } & $8.00 \pm 1.3$ & $1.60 \pm 0.12$ & $2.35 \pm 0.30$ & $0.42 \pm 0.03$ \\
\hline \multicolumn{2}{|c|}{ Methane yield (NmL/gVS) } & $0.56 \pm 0.09$ & $2.42 \pm 0.08$ & $8.47 \pm 0.25$ & $1.83 \pm 0.13$ \\
\hline \multirow{4}{*}{ Digestate quality } & $\mathrm{pH}$ & $5.49 \pm 0.04$ & $6.21 \pm 0.07$ & $5.20 \pm 0.02$ & $4.89 \pm 0.05$ \\
\hline & $\mathrm{sCOD}(\mathrm{mg} / \mathrm{L})$ & $24,143 \pm 514$ & $26,010 \pm 410$ & $65,167 \pm 4250$ & $88,866 \pm 7688$ \\
\hline & TVFA (mg/L) & $12,026 \pm 189$ & $12,703 \pm 320$ & $56,473 \pm 1217$ & $61,060 \pm 1324$ \\
\hline & Ammonium nitrogen $(\mathrm{mg} / \mathrm{L})$ & $152.7 \pm 7.2$ & $243.3 \pm 5.1$ & $524.0 \pm 16.8$ & $322.3 \pm 12.0$ \\
\hline
\end{tabular}

The hyperthermophilic pretreatment resulted in the solubilization of plant material with only a minor production of methane and hydrogen, which is in line with the observations of Wang et al. [15]. Generally, the solubilization rate was greater for the leaves, especially when treated at $80^{\circ} \mathrm{C}$. Under such conditions, the soluble COD and total volatile fatty acids reached $88,866 \mathrm{mg} / \mathrm{L}$ and $61,060 \mathrm{mg} / \mathrm{L}$, respectively, whereas the corresponding figures measured at $70{ }^{\circ} \mathrm{C}$ were $65,167 \mathrm{mg} / \mathrm{L}$ and $56,473 \mathrm{mg} / \mathrm{L}$, respectively. The highest respective values of the soluble COD and TVFA reported for the pretreated grass were $26,010 \mathrm{mg} / \mathrm{L}$ and $12,703 \mathrm{mg} / \mathrm{L}$, and this could be attributed to the higher water content in the grass. The production of fatty acids resulted in a $\mathrm{pH}$ decrease, which, in turn, could enhance the breakdown of the lignocellulosic structures. The release of TVFA and the increase in SCOD corresponded to the production of ammonium nitrogen; however, their concentrations were generally low due to the specific characteristics of substrates mainly built of lignocellulose. The highest N-NH4 concentrations of $524 \mathrm{mg} / \mathrm{L}$ were reported for the leaves treated at $70{ }^{\circ} \mathrm{C}$. Surprisingly, for the same material the concentration of ammonium nitrogen was lower at $80^{\circ} \mathrm{C}$, contradicting the trend observed for the grass. This might have been due to a very low $\mathrm{pH}$ observed for this series, which hampered the release of ammonia.

\subsection{Co-Digestion Second Stage}

The methane and hydrogen yields reported in the co-digestion runs are summarized in Table 3 and Figures 1 and 2 as the curves of cumulative productions. Overall, the highest biogas yields were observed when the process was operated at $70{ }^{\circ} \mathrm{C}$ and $55{ }^{\circ} \mathrm{C}$ in the subsequent stages and were thereby consistent with the previous findings $[11,13]$. Despite a greater solubilization rate at $80^{\circ} \mathrm{C}$ expressed by higher concentrations of VFA and sCOD, the co-digestion process in the second step performed a bit worse (the experiments with leaves) or at a comparable level (the experiments with grass) compared to the runs with a $70{ }^{\circ} \mathrm{C}$ pretreatment step. In turn, at the lower temperature in the co-digestion stage the lagphase was clearly extended, which was especially visible in the experiments with leaves. Another interesting finding is the highest methane yield observed in mono-digestion experiments. The highest methane production of $387.4 \mathrm{NmL} / \mathrm{gVS}$ was reported in the 
series with leaves in a two-stage process performed at $70{ }^{\circ} \mathrm{C}$ and $55^{\circ} \mathrm{C}$ in the subsequent steps. In the same configuration, the $75 \%$ addition of kitchen waste to the leaves gave $328 \mathrm{NmL} / \mathrm{gVS}$ of methane, whereas for the $25 \%$ addition of KW, the yield of methane was only $242 \mathrm{NmL} / \mathrm{gVS}$. In the experiments with grass, the maximum methane production of $321 \mathrm{NmL} / \mathrm{gVS}$ was reported in a two-step mono-digestion process operated at $80 / 55^{\circ} \mathrm{C}$, whereas with the addition of $75 \%$ and $25 \%$ kitchen waste, the methane yield dropped to $275 \mathrm{NmL} / \mathrm{gVS}$ and $122 \mathrm{NmL} / \mathrm{gVS}$. However, when the process was performed at $70 / 55^{\circ} \mathrm{C}$, the $75 \%$ addition of KW slightly improved the methane production, but the methane yield obtained in the mono-digestion of grass was insignificantly lower. Literature data on the anaerobic digestion of garden waste with food or kitchen waste are divergent. Brown and Li [19] and Chen et al. [20] reported an increased biogas production with a greater proportion of food waste to green waste. By contrast, Zhang et al. [21] obtained the maximum methane production in a co-digestion of yard waste supplemented with only $10 \%$ food waste. High methane production did not correspond with the increased hydrogen yield. The production of hydrogen in the mono-digestion experiments did not reach $30 \mathrm{NmL} / \mathrm{gVS}$, and generally, lower values were observed for the leaves. In contrast, the greatest hydrogen production of $87.5 \mathrm{NmL} / \mathrm{gVS}$ was reported in a two-stage $70 / 55^{\circ} \mathrm{C}$ process treating the grass with a $50 \%$ addition of $\mathrm{KW}$, but for the other proportions the yields were also high. In the experiments with leaves, the highest production of hydrogen (70 NmL/gVS) was reported with the addition of $75 \% \mathrm{KW}$ and the process operation at $70 / 55^{\circ} \mathrm{C}$. Low hydrogen yields reported for garden wastes can be linked to the formation of inhibitory compounds during the thermal decomposition of lignocellulose, including furfural, levulinic acid, or vanillin [9]. The simultaneous production of methane and hydrogen from lignocellulosic materials is not surprising and has been reported and discussed in the previous study [11]. In batch experiments, hydrogen is mainly produced within $24-48 \mathrm{~h}$, then the production ceases. This creates a high partial pressure of hydrogen, which hinders methane production due to the inhibition of syntrophy [22,23]. However, after a few days, the hydrogen is consumed, and methane production is not further affected.

Table 3. Total methane and hydrogen yields in the second-stage co-digestion runs.

\begin{tabular}{|c|c|c|c|c|c|c|c|c|c|c|}
\hline \multirow{2}{*}{ Substrate } & \multirow{2}{*}{$\begin{array}{c}\text { Pretreatment } \\
\text { Temperaturę for } \\
\text { GW }\end{array}$} & \multirow{2}{*}{$\begin{array}{l}\text { Co-Digestion } \\
\text { Temperature }\end{array}$} & \multicolumn{4}{|c|}{$\begin{array}{l}\text { Methane Yields (NmL/gVS) } \\
\text { for GW/KW Proportions }\end{array}$} & \multicolumn{4}{|c|}{$\begin{array}{l}\text { Hydrogen Yields (NmL/gVS) } \\
\text { for GW/KW Proportions }\end{array}$} \\
\hline & & & $25 / 75$ & $50 / 50$ & $75 / 25$ & $0 / 100$ & $25 / 75$ & $50 / 50$ & $75 / 25$ & $0 / 100$ \\
\hline \multirow{4}{*}{ Grass/KW } & \multirow[b]{2}{*}{$70^{\circ} \mathrm{C}$} & $55^{\circ} \mathrm{C}$ & $\begin{array}{c}241.8 \pm \\
4.5\end{array}$ & $\begin{array}{c}258.5 \pm \\
3.6\end{array}$ & $305 \pm 2.9$ & $\begin{array}{c}295.6 \pm \\
8.1\end{array}$ & $\begin{array}{c}80.0 \pm \\
1.8\end{array}$ & $\begin{array}{c}87.5 \pm \\
1.1\end{array}$ & $\begin{array}{c}84.3 \pm \\
0.8\end{array}$ & $27.2 \pm 3.3$ \\
\hline & & $35^{\circ} \mathrm{C}$ & $\begin{array}{c}182.1 \pm \\
3.8\end{array}$ & $\begin{array}{c}149.0 \pm \\
3.7\end{array}$ & $\begin{array}{c}99.0 \pm \\
3.9\end{array}$ & $\begin{array}{c}244.1 \pm \\
1.7\end{array}$ & $\begin{array}{c}32.7 \pm \\
0.6\end{array}$ & $\begin{array}{c}47.7 \pm \\
0.7\end{array}$ & $\begin{array}{c}49.0 \pm \\
1.1\end{array}$ & $23.5 \pm 3.2$ \\
\hline & \multirow[b]{2}{*}{$80^{\circ} \mathrm{C}$} & $55^{\circ} \mathrm{C}$ & $\begin{array}{c}122.1 \pm \\
7.6\end{array}$ & $\begin{array}{c}162.7 \pm \\
2.8\end{array}$ & $\begin{array}{c}275.3 \pm \\
6.4\end{array}$ & $321 \pm 4.2$ & $\begin{array}{c}37.8 \pm \\
2.6\end{array}$ & $\begin{array}{c}54.3 \pm \\
0.8\end{array}$ & $\begin{array}{c}71.2 \pm \\
0.7\end{array}$ & $16.2 \pm 0.3$ \\
\hline & & $35^{\circ} \mathrm{C}$ & $\begin{array}{c}241.3 \pm \\
2.8\end{array}$ & $\begin{array}{c}232.4 \pm \\
9.8\end{array}$ & $\begin{array}{l}305.1 \pm \\
8.2\end{array}$ & $\begin{array}{c}306.4 \pm \\
1.4\end{array}$ & $\begin{array}{c}42.4 \pm \\
0.9\end{array}$ & $\begin{array}{l}53.4 \pm \\
1.3\end{array}$ & $\begin{array}{c}60.7 \pm \\
1.2\end{array}$ & $27.5 \pm 0.2$ \\
\hline \multirow{4}{*}{ Leaves/KW } & \multirow[b]{2}{*}{$70^{\circ} \mathrm{C}$} & $55^{\circ} \mathrm{C}$ & $\begin{array}{c}241.9 \pm \\
5.5\end{array}$ & $\begin{array}{c}272.4 \pm \\
7.7\end{array}$ & $\begin{array}{c}328.0 \pm \\
7.9\end{array}$ & $\begin{array}{c}387.4 \pm \\
2.2\end{array}$ & $\begin{array}{c}45.7 \pm \\
0.9\end{array}$ & $\begin{array}{c}52.0 \pm \\
1.1\end{array}$ & $\begin{array}{c}70.0 \pm \\
1.2\end{array}$ & $25.4 \pm 0.2$ \\
\hline & & $35^{\circ} \mathrm{C}$ & $\begin{array}{c}209.7 \pm \\
8.8\end{array}$ & $\begin{array}{c}193.5 \pm \\
8.1\end{array}$ & $\begin{array}{c}117.2 \pm \\
6.7\end{array}$ & $\begin{array}{c}365.1 \pm \\
3.6\end{array}$ & $\begin{array}{c}24.7 \pm \\
0.7\end{array}$ & $\begin{array}{c}35.6 \pm \\
1.3\end{array}$ & $\begin{array}{c}32.0 \pm \\
0.8\end{array}$ & $23.4 \pm 0.4$ \\
\hline & \multirow{2}{*}{$80^{\circ} \mathrm{C}$} & $55^{\circ} \mathrm{C}$ & $\begin{array}{c}234.2 \pm \\
8.3\end{array}$ & $\begin{array}{c}279.0 \pm \\
13.7\end{array}$ & $\begin{array}{c}291.3 \pm \\
11.2\end{array}$ & $\begin{array}{c}235.1 \pm \\
0.8\end{array}$ & $\begin{array}{c}14.9 \pm \\
0.6\end{array}$ & $\begin{array}{c}21.0 \pm \\
1.0\end{array}$ & $\begin{array}{c}25.0 \pm \\
1.0\end{array}$ & $24.1 \pm 0.3$ \\
\hline & & $35^{\circ} \mathrm{C}$ & $\begin{array}{c}28.0 \pm \\
2.0\end{array}$ & $\begin{array}{c}126.5 \pm \\
14.9\end{array}$ & $\begin{array}{c}300.1 \pm \\
14.1\end{array}$ & $\begin{array}{c}219.0 \pm \\
0.6\end{array}$ & $1.9 \pm 0.1$ & $7.9 \pm 0.9$ & $\begin{array}{c}19.0 \pm \\
0.8\end{array}$ & $5.4 \pm 0.2$ \\
\hline
\end{tabular}

GW—garden waste (grass or leaves); KW—kitchen waste. Greater color intensity indicates higher methane or hydrogen yield. 
Temperature of Grass Pretreatment $\left({ }^{\circ} \mathrm{C}\right)$

70
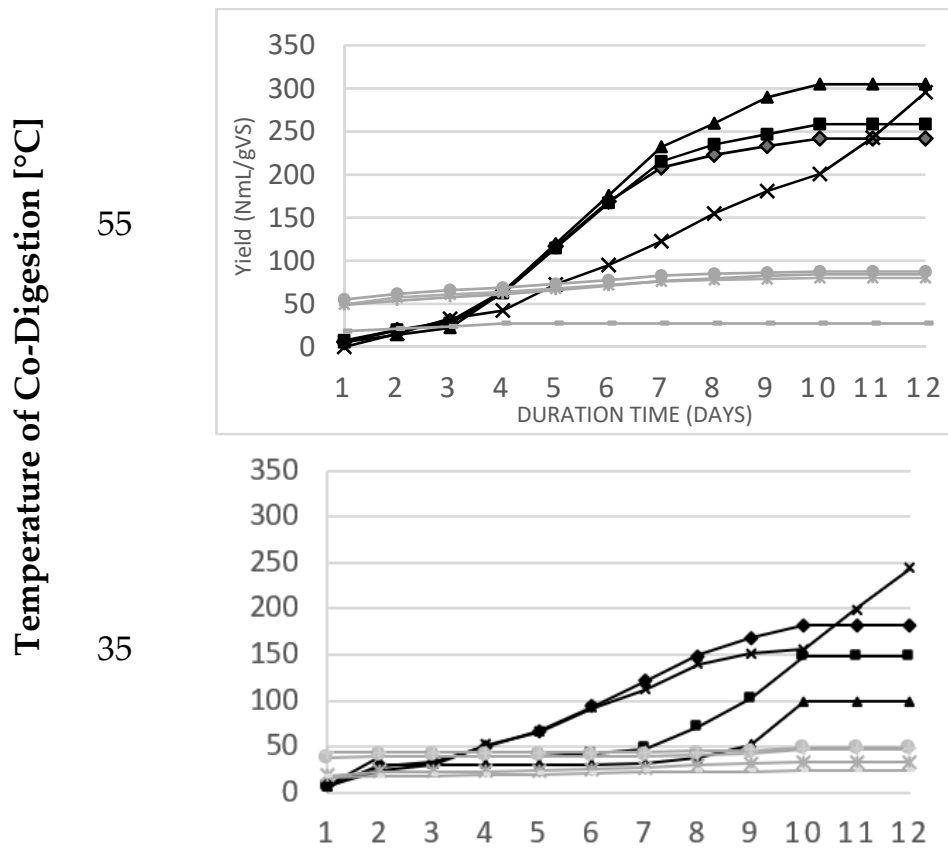

80
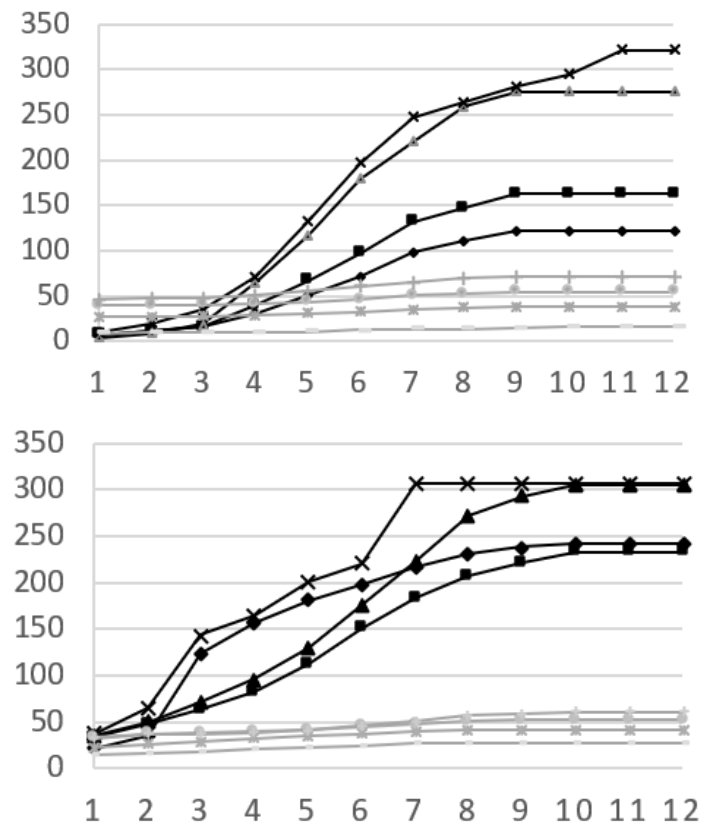

$$
\begin{aligned}
& \rightarrow-\mathrm{M} \mathrm{25/75-M} \mathrm{50/50-M} \mathrm{75/25-M} \mathrm{0/100} \\
& *-\mathrm{H} \text { 25/75 - - H 50/50 - }
\end{aligned}
$$

Figure 1. Cumulative methane and hydrogen yields from co-digestion of kitchen waste and grass after hyperthermophilic pretreatment. M 25/75-mesophilic co-digestion of pretreated grass with 25\% addition of kitchen waste. M 50/50mesophilic co-digestion of pretreated grass with 50\% addition of kitchen waste. M 75/25-mesophilic co-digestion of pretreated grass with $25 \%$ addition of kitchen waste. M 0/100-mesophilic mono-digestion of pretreated grass. T 25/75thermophilic co-digestion of pretreated grass with 25\% addition of kitchen waste. T 50/50 — thermophilic co-digestion of pretreated grass with 50\% addition of kitchen waste. T 75/25-thermophilic co-digestion of pretreated grass with $25 \%$ addition of kitchen waste. T 0/100—-thermophilic mono-digestion of pretreated grass.

The literature describing the co-digestion of garden and kitchen wastes or other waste groups with a hyperthermophilic pretreatment step is very limited. Abbreu et al. [16] conducted co-digestion experiments performed at $70^{\circ} \mathrm{C}$ and $37^{\circ} \mathrm{C}$ in the subsequent stages with garden and food wastes. They obtained the hydrogen and methane production rates of $46 \mathrm{~mL} / \mathrm{gVS}$ and $682 \mathrm{~mL} / \mathrm{kgVS}$, respectively, for the mixture of garden/food waste of 90/10; however, the substrates were jointly treated in both steps with an additional inoculation of the hyperthermophilic digester by a pure culture of Caldicellulosiruptor saccharolyticus. A two-step anaerobic digestion of shredded grass and sewage sludge was investigated by Wang et al. [15]. The maximum methane production of $335 \mathrm{NmL} / \mathrm{kgVS}$ was reported in that study, and the best operating conditions were 3 days at $80^{\circ} \mathrm{C}$ in the hydrolysis stage followed by anaerobic digestion at $55{ }^{\circ} \mathrm{C}$. The cited authors did not observe hydrogen production in either of the steps. 


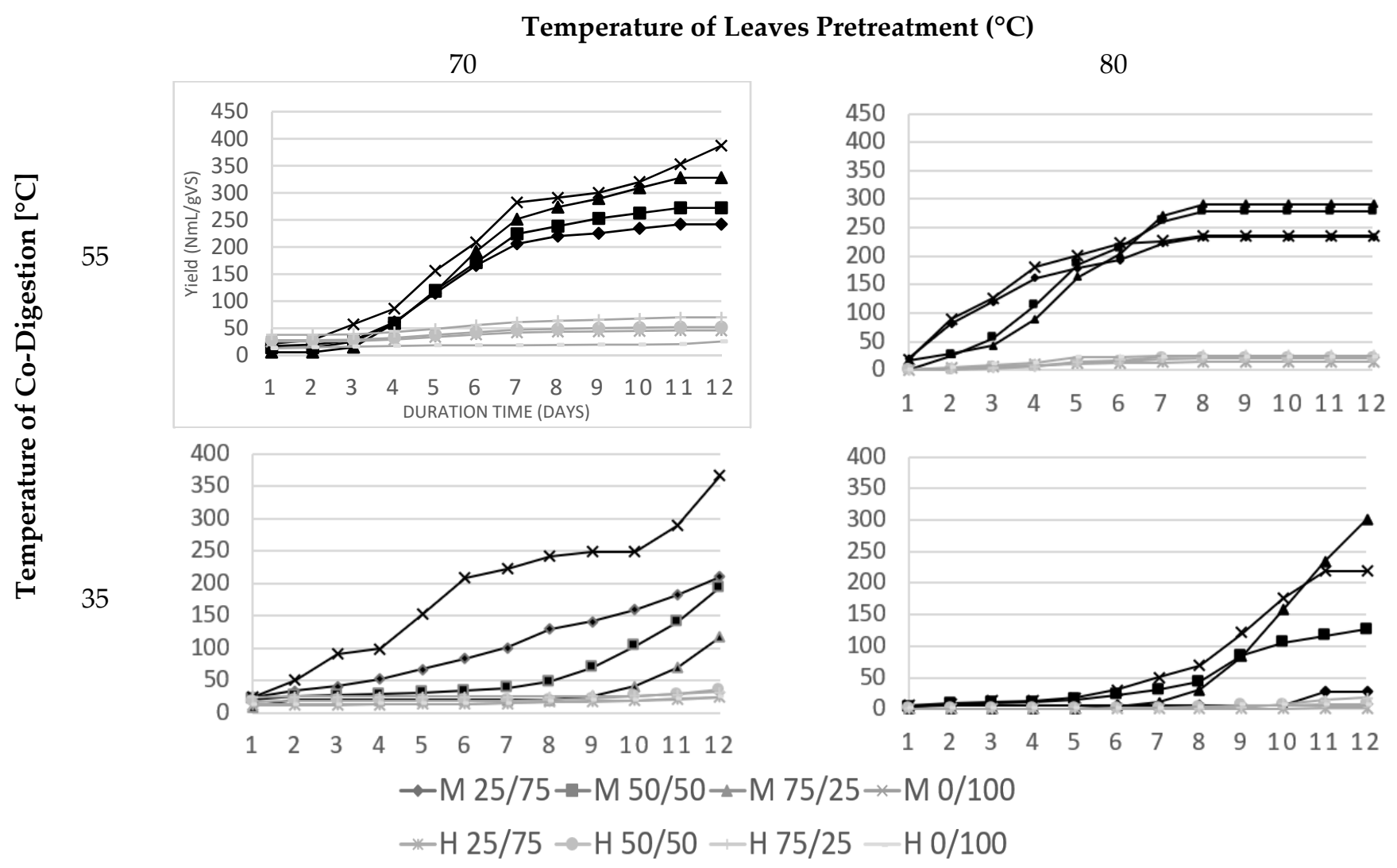

Figure 2. Cumulative methane and hydrogen yields from co-digestion of kitchen waste and leaves after hyperthermophilic pretreatment. M 25/75-mesophilic co-digestion of pretreated leaves with 25\% addition of kitchen waste. M 50/50mesophilic co-digestion of pretreated leaves with 50\% addition of kitchen waste. M 75/25-mesophilic co-digestion of pretreated leaves with $25 \%$ addition of kitchen waste. M 0/100-mesophilic mono-digestion of pretreated leaves. T 25/75thermophilic co-digestion of pretreated leaves with $25 \%$ addition of kitchen waste. T 50/50-thermophilic co-digestion of pretreated leaves with $50 \%$ addition of kitchen waste. T 75/25-thermophilic co-digestion of pretreated leaves with $25 \%$ addition of kitchen waste. T 0/100—-thermophilic mono-digestion of pretreated leaves.

\section{Materials and Methods}

\subsection{Substrates and Inoculum}

The following materials were applied for the experiments: grass, fruit tree leaves, and kitchen waste collected between September and October 2019 from individual households. Fresh grass after mowing was shredded in a grinder (FIMAR TS-32D400V) (RM Gastro s.r.o., Veseli and Luznici, Czech Republik) and stored in $500 \mathrm{~mL}$ containers at $-18{ }^{\circ} \mathrm{C}$ until use. Leaves, after drying at $20-25^{\circ} \mathrm{C}$ for 7 days, were milled with a kitchen blender and placed in a sealed vessel to prevent moisture. Kitchen waste was collected daily for two months, kept at $-18{ }^{\circ} \mathrm{C}$ and then ground and mixed to obtain a relatively uniform mass for all the experimental processes. It mainly contained fruit and vegetable leftovers as well as meat and cheese scraps, tea leaves, and other items. Anaerobic sludge serving as inoculum was delivered from the anaerobic digester operated at the Wastewater Treatment Plant in Zdunska Wola. The composition of both the substrates and the inoculum is depicted in Table 1.

\subsection{Experiments}

Batch experiments were performed using a laboratory installation, as shown in Figure 3. Grass or leaves alone were first subjected to the hyperthermophilic pretreatment, then mixed with kitchen waste in various proportions and further digested in the second co-digestion step operated in two temperature regimes of $35^{\circ} \mathrm{C}$ and $55^{\circ} \mathrm{C}$. The experiments in both stages were carried out using a series of cylindrical glass tanks with 
a capacity of $1 \mathrm{dm}^{3}$ each. The tanks were placed in a thermostatic chamber to ensure constant temperature and connected to the gas collecting bottles for the measurement of daily biogas production. The tanks were manually mixed twice a day.

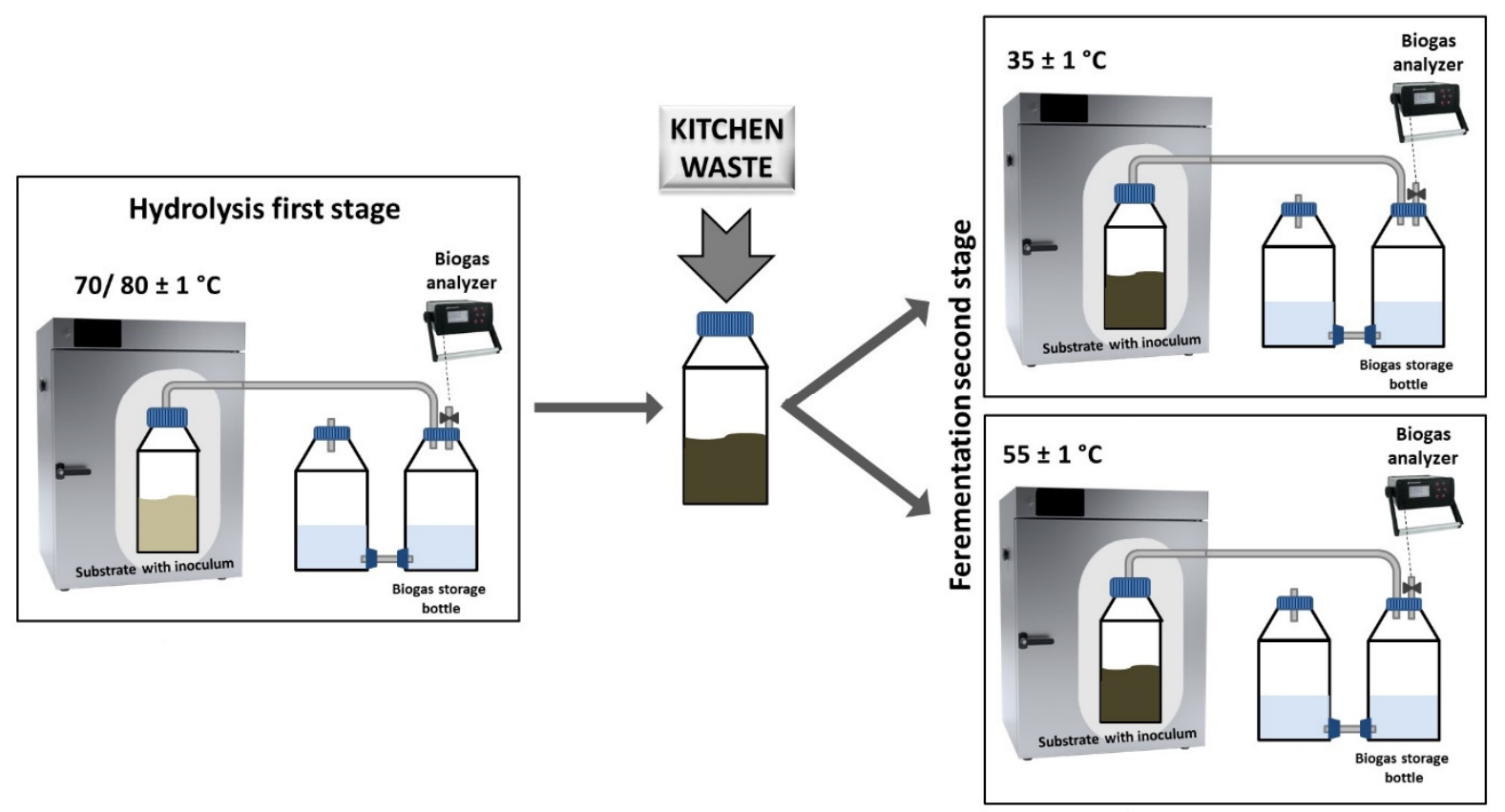

Figure 3. Laboratory setup used in the study.

\subsubsection{Hyperthermophilic Pretreatment of Grass and Leaves}

The hyperthermophilic pretreatment was carried out at temperatures of $70{ }^{\circ} \mathrm{C}$ and $80{ }^{\circ} \mathrm{C}$. Due to high density, both substrates were diluted with water as follows: $250 \mathrm{~g}$ of grass blended with $250 \mathrm{~g}$ of water, and $150 \mathrm{~g}$ of leaves mixed with $350 \mathrm{~g}$ of water, as shown in Table 2. The mixtures were then placed in the digestion tanks with no addition of inoculum at this stage. Before closure, the top of each tank was flushed with nitrogen gas to provide anaerobic conditions. Considering the earlier experiences, the hyperthermophilic pretreatment time was set for 3 days [18]. After completion of the process, the digested materials were analyzed for $\mathrm{pH}$, soluble $\mathrm{COD}$, ammonium nitrogen, and volatile fatty acids.

\subsubsection{Co-Digestion Second Stage}

The pretreated grass or leaves were mixed with kitchen waste in three proportions on a wet mass basis, as shown in Table 3 . Then, the mixtures were blended with $500 \mathrm{~g}$ of anaerobic sludge serving as inoculum to obtain a proportion of I/S $=2(\mathrm{gVS} / \mathrm{gVS})$ and transferred to the digestion tanks. Additionally, the mixtures of inoculum with grass or leaves alone were prepared in a similar way, and these were considered as the reference series. The I/S proportion was chosen based on our previous experiences with lignocellulosic substrates [11,24] as well as the guidelines of Angelideki et al. [25]. The anaerobic digestion in the second step was carried out at the temperatures of $55^{\circ} \mathrm{C}$ and $35^{\circ} \mathrm{C}$, and the experiments were continued until no biogas production was observed. The experimental runs were performed in 3 replicates and the results are presented as averages.

\subsection{Analytical Methods}

Total solids (TS), volatile solids (VS), and pH were determined based on Standard Methods for the Examination of Water and Wastewater [26]. A modified dichromate method by HACH-Lange no. LCK 514 was applied for the measurement of soluble chemical oxygen demand (sCOD). Total volatile fatty acids (TVFAs) were analyzed using a DR3900 spectrophotometer and a HACH-Lange test no. LCK365. A modified Nessler method by $\mathrm{HACH}$-Lange no. 8038 was applied for the determination of ammonium nitrogen $\left(\mathrm{NH}^{+}{ }^{+}\right.$ 
N). The analysis of total carbon, nitrogen, hydrogen, sulfur, and phosphorus was carried out using a Flash Elemental Analyzer (Thermo Finnigan, Rodano, Italy) and the manufacturer's procedures. The composition of biogas was determined with a gas analyzer (Nanosens DP-27 BIO) (Nanosens, Tarnowo Podgórne, Poland). Each analysis was performed in triplicate, and the calculations of mean values and standard deviations were calculated in Microsoft Excel 2010.

\section{Conclusions}

The experiments showed that the addition of kitchen waste to garden waste significantly improves hydrogen production but does not increase methane yield. Considering the overall process performance, the highest overall biogas production can be achieved using a 3-day pretreatment of garden waste at $70{ }^{\circ} \mathrm{C}$ followed by a co-digestion with $75 \%$ kitchen waste at $55{ }^{\circ} \mathrm{C}$. Under such conditions, the maximum methane and hydrogen yields achieved for grass with $75 \% \mathrm{KW}$ were $305 \mathrm{NmLCH}_{4} / \mathrm{gVS}$ and $88 \mathrm{NmLH}_{2} / \mathrm{gVS}$, whereas the corresponding values for leaves with $75 \% \mathrm{KW}$ were $328 \mathrm{NmLCH}_{4} / \mathrm{gVS}$ and $70 \mathrm{NmLH}_{2} / \mathrm{gVS}$.

Author Contributions: P.L.: Conceptualization, Methodology, Investigation, Data Curation, WritingOriginal Draft, Writing — Review and Editing. S.B.: Conceptualization, Methodology, Formal Analysis, Resources, Project Administration, Supervision, Funding Acquisition, Writing-Original Draft, Writing-Review and Editing. Both authors have read and agreed to the published version of the manuscript.

Funding: This study was financially supported by the Regional Fund for Environmental Protection and Water Management in Lodz, Poland, grant number 60/BN/D/2019.

Institutional Review Board Statement: Not applicable.

Informed Consent Statement: Not applicable.

Acknowledgments: The authors kindly acknowledge the management and staff of the Wastewater Treatment Plant in Zdunska Wola for allowing the collection of anaerobic sludge for the experiments.

Conflicts of Interest: The authors declare that they have no known competing financial interests or personal relationships that could have appeared to influence the work reported in this paper.

Ethical Approval and Consent to Participate: All authors confirmed the authenticity and accuracy of the results and agree on their publication.

\section{References}

1. The European Commission. Closing the Loop-An EU Action Plan for the Circular Economy. In Communication from the Commission to the European Parliament, the Council, the European Economic and Social Committee and the Committee of the Regions; European Commission: Brussels, Belgium, 2015.

2. Sfez, S.; De Meester, S.; Vlaeminck, S.E.; Dewulf, J. Improving the resource footprint evaluation of products recovered from wastewater: A discussion on appropriate allocation in the context of circular economy. Resour. Conserv. Recycl. 2019, 148, 132-144. [CrossRef]

3. Neczaj, E.; Grosser, A. Circular Economy in Wastewater Treatment Plant-Challenges and Barriers. Proceedings 2018, $2,614$. [CrossRef]

4. Bianco, M. Circular economy and WWTPs: Water reuse and biogas production. In The Italian Water Industry: Cases of Excellence; Springer International Publishing: Berlin/Heidelberg, Germany, 2018; pp. 237-257. ISBN 9783319713366.

5. Główny Urząd Statystyczny. Ochrona Środowiska 2019. Available online: stat.gov.pl (accessed on 29 November 2019).

6. Yun, Y.M.; Lee, M.K.; Im, S.W.; Marone, A.; Trably, E.; Shin, S.R.; Kim, M.G.; Cho, S.K.; Kim, D.H. Biohydrogen production from food waste: Current status, limitations, and future perspectives. Bioresour. Technol. 2018, 248, 79-87. [CrossRef] [PubMed]

7. Braguglia, C.M.; Gallipoli, A.; Gianico, A.; Pagliaccia, P. Anaerobic bioconversion of food waste into energy: A critical review. Bioresour. Technol. 2018, 248, 37-56. [CrossRef] [PubMed]

8. Urbaniec, K.; Bakker, R.R. Biomass residues as raw material for dark hydrogen fermentation-A review. Int. J. Hydrogen Energy 2015, 40, 3648-3658. [CrossRef]

9. Sivagurunathan, P.; Kumar, G.; Mudhoo, A.; Rene, E.R.; Saratale, G.D.; Kobayashi, T.; Xu, K.; Kim, S.H.; Kim, D.H. Fermentative hydrogen production using lignocellulose biomass: An overview of pre-treatment methods, inhibitor effects and detoxification experiences. Renew. Sustain. Energy Rev. 2017, 77, 28-42. [CrossRef] 
10. Lo, Y.C.; Lu, W.C.; Chen, C.Y.; Chang, J.S. Dark fermentative hydrogen production from enzymatic hydrolysate of xylan and pretreated rice straw by Clostridium butyricum CGS5. Bioresour. Technol. 2010, 101, 5885-5891. [CrossRef]

11. Liczbiński, P.; Borowski, S. Effect of hyperthermophilic pretreatment on methane and hydrogen production from garden waste under mesophilic and thermophilic conditions. Bioresour. Technol. 2021, 335, 125264. [CrossRef]

12. Algapani, D.E.; Qiao, W.; Su, M.; di Pumpo, F.; Wandera, S.M.; Adani, F.; Dong, R. Bio-hydrolysis and bio-hydrogen production from food waste by thermophilic and hyperthermophilic anaerobic process. Bioresour. Technol. 2016, 216, 768-777. [CrossRef]

13. Lee, M.; Hidaka, T.; Hagiwara, W.; Tsuno, H. Comparative performance and microbial diversity of hyperthermophilic and thermophilic co-digestion of kitchen garbage and excess sludge. Bioresour. Technol. 2009, 100, 578-585. [CrossRef]

14. Wang, F.; Hidaka, T.; Tsuno, H.; Tsubota, J. Co-digestion of polylactide and kitchen garbage in hyperthermophilic and thermophilic continuous anaerobic process. Bioresour. Technol. 2012, 112, 67-74. [CrossRef] [PubMed]

15. Wang, F.; Hidaka, T.; Tsumori, J. Enhancement of anaerobic digestion of shredded grass by co-digestion with sewage sludge and hyperthermophilic pretreatment. Bioresour. Technol. 2014, 169, 299-306. [CrossRef] [PubMed]

16. Abreu, A.A.; Tavares, F.; Alves, M.M.; Cavaleiro, A.J.; Pereira, M.A. Garden and food waste co-fermentation for biohydrogen and biomethane production in a two-step hyperthermophilic-mesophilic process. Bioresour. Technol. 2019, 278, 180-186. [CrossRef]

17. Xia, A.; Cheng, J.; Murphy, J.D. Innovation in biological production and upgrading of methane and hydrogen for use as gaseous transport biofuel. Biotechnol. Adv. 2016, 34, 451-472. [CrossRef] [PubMed]

18. Liczbinski, P.; Borowski, S. Hyperthermophilic treatment of grass and leaves to produce hydrogen, methane and VFA-rich digestate: Preliminary results. Energies 2020, 13, 2814. [CrossRef]

19. Brown, D.; Li, Y. Solid state anaerobic co-digestion of yard waste and food waste for biogas production. Bioresour. Technol. 2013, 127, 275-280. [CrossRef]

20. Chen, X.; Yan, W.; Sheng, K.; Sanati, M. Comparison of high-solids to liquid anaerobic co-digestion of food waste and green waste. Bioresour. Technol. 2014, 154, 215-221. [CrossRef]

21. Zhang, L.; Loh, K.C.; Zhang, J. Food waste enhanced anaerobic digestion of biologically pretreated yard waste: Analysis of cellulose crystallinity and microbial communities. Waste Manag. 2018, 79, 109-119. [CrossRef]

22. Kouzuma, A.; Kato, S.; Watanabe, K. Microbial interspecies interactions: Recent findings in syntrophic consortia. Front. Microbiol. 2015, 6, 477. [CrossRef]

23. Braga Nan, L.; Trably, E.; Santa-Catalina, G.; Bernet, N.; Delgenès, J.-P.; Escudié, R. Biomethanation processes: New insights on the effect of a high $\mathrm{H} 2$ partial pressure on microbial communities. Biotechnol. Biofuels 2020, 13, 1-17. [CrossRef]

24. Borowski, S.; Kucner, M.; Czyżowska, A.; Berłowska, J. Co-digestion of poultry manure and residues from enzymatic saccharification and dewatering of sugar beet pulp. Renew. Energy 2016, 99, 492-500. [CrossRef]

25. Angelidaki, I.; Alves, M.; Bolzonella, D.; Borzacconi, L.; Campos, J.L.; Guwy, A.J.; Kalyuzhnyi, S.; Jenicek, P.; van Lier, J.B. Defining the biomethane potential (BMP) of solid organic wastes and energy crops: A proposed protocol for batch assays. Water Sci. Technol. 2009, 59, 927-934. [CrossRef] [PubMed]

26. American Public Health Association. Standard Methods for the Examination of Water and Wastewater, 21st ed.; American Public Health Association: Washington, DC, USA, 2005. 